\title{
Treatment of bladder dysfunction with solifenacin: is there a risk of dementia or cognitive impairment?
}

\author{
L.P. Dantas ${ }^{1,2 \oplus}$, A.R.C.C. Forte ${ }^{1 \oplus}$, B.C. Lima $^{1 \oplus}$, C.N.S. Sousa ${ }^{1 \oplus}$, E.C. Vasconcelos ${ }^{1 \oplus}$ \\ P.H.C. Lessa ${ }^{3 \oplus}$, R.F. Vieira ${ }^{30}$, M.C.A. Patrocínio ${ }^{4,5}$, and S.M.M. Vasconcelos ${ }^{10}$
}

${ }^{1}$ Laboratório de Neuropsicofarmacologia, Núcleo de Pesquisa e Desenvolvimentos de Medicamentos, Departamento de Fisiologia e Farmacologia, Faculdade de Medicina, Universidade Federal do Ceará, Fortaleza, CE, Brasil ${ }^{2}$ Departamento de Urologia, Hospital Geral de Fortaleza, Fortaleza, CE, Brasi ${ }^{3}$ Universidade Federal do Amapá, Macapá, AP, Brasil

${ }^{4}$ Faculdade de Medicina, Centro Universitário Christus, Fortaleza, CE, Brasil ${ }^{5}$ Departamento de Anestesiologia, Instituto Dr. Jose Frota, Fortaleza, CE, Brasil

\begin{abstract}
The use of bladder antimuscarinics is very common in the elderly. However, recent population-based studies that assessed the use of anticholinergics or bladder antimuscarinics showed an increased risk of dementia when these drugs were used for a prolonged period. Several of these population-based studies included patients who used solifenacin, which is a bladder antimuscarinic released in 2005 with the prospect of being a more selective antimuscarinic for M3 receptors (M3R), which could make it a safer drug when trying to avoid unwanted effects of older bladder antimuscarinics such as oxybutynin, especially with regard to changes in cognition. Since the various bladder antimuscarinics have distinct pharmacological characteristics, such as in the ability to penetrate the blood-brain barrier, in selectivity for muscarinic receptors, and in brain efflux mechanisms, their effects on the central nervous system (CNS) may vary. Solifenacin was the drug selected in this review, which aims to describe the results of several articles published in recent years reporting the effects of solifenacin on cognition or the risk of dementia development. Although preclinical studies show that solifenacin can also act on brain M1 receptors (M1R), short-term clinical studies have shown it to be safe for cognition. However, there are no long-term randomized studies that prove the safety of this drug for the CNS. Thus, until the safety of solifenacin has been established by long-term studies, it seems advisable to avoid prolonged use of this drug in elderly patients.
\end{abstract}

Key words: Solifenacin; Dementia; Cognitive impairment; Anticholinergics; Bladder antimuscarinics

\section{Introduction}

Recently, some population-based studies have been published associating the use of antimuscarinics in the elderly (including antimuscarinics for the treatment of voiding dysfunction) to an increased incidence of dementia and an increase in mortality (1-6). Anticholinergics have been frequently used in elderly patients, reaching $33 \%$ in the elderly population with dementia (7). As the incidence of overactive bladder $(O A B)$ and urinary incontinence also increases with age, the coexistence of voiding dysfunctions and dementia as well as the high use of bladder antimuscarinics is common in elderly patients (8). In a study that evaluated 3.78 million elderly patients aged 65 years and older with dementia, it was reported that 1.02 million $(26.9 \%)$ were taking potentially inappropriate anticholinergic medications, with the most frequently prescribed drugs being oxybutynin, solifenacin, paroxetine, tolterodine, promethazine, and cyclobenzaprine, showing a high prevalence of prescriptions for bladder antimuscarinics at this age (9). However, the evaluation of each of these antimuscarinics in relation to their effects on the central nervous system (CNS) must take into account each drug individually, since the different antimuscarinics have specific pharmacological characteristics that can interfere with the concentration and action of the drug in the CNS (10). Solifenacin, approved for clinical use in 2005 , is one of the most used antimuscarinics for the treatment of bladder dysfunction (11-14) and has been associated with changes in cognition $(1,2,6,15)$. Therefore, our aim was to review the literature on the effects of solifenacin on cognition or risk of dementia and to clarify whether this risk is also significant with a drug with greater selectivity for M3 receptors (M3R), such as solifenacin.

Correspondence: S.M.M. Vasconcelos: <silvaniavasconcelos@ufc.br $><$ silvania_vasconcelos@yahoo.com.br> 


\section{Material and Methods}

For this review article, we performed a search in PubMed and SCOPUS databases with the following keywords: 'solifenacin' or 'anticholinergics' or 'antimuscarinics' plus 'dementia' or 'Alzheimer' or 'cognition' or 'cognitive impairment'. Preclinical studies and clinical trials on solifenacin were evaluated.

\section{Cholinergic mechanisms in dementia}

Dementia is a heterogeneous clinical syndrome that can be classified into four main subtypes: Alzheimer's disease (AD), vascular dementia, frontotemporal dementia, and Lewy body dementia, with Alzheimer's disease being the most common (16). There are other causes of mild cognitive impairment (impaired cognition without decline in daily function) and dementia that may occur during life, such as vitamin deficiency (thiamine, vitamin B12), hypothyroidism, hydrocephalus with normal pressure, alcoholism, infections (e.g., HIV), intracranial masses, brain injury due to trauma (17). The importance of using some medications in the elderly with a potential deleterious effect on the central nervous system, such as anticholinergics, is also highlighted (18).

Acetylcholine is a neurotransmitter widely distributed in the CNS (Table S1) that binds to cerebral muscarinic receptors (M1R, M2R, M3R, M4R, M5R) and is essential for cognitive function. It is abundant in the hippocampus and has an important mediating role in the formation of semantic and episodic memory. The neurotransmitter has been associated with age-related dementias, as occurs in $A D$ where the cholinergic system is greatly affected (19). Patients with early $A D$ can present with atrophy of the cholinergic system in the basal forebrain, with a decrease in the number of cholinergic neurons and a lower transcription of the choline-acetyltransferase enzyme, which is necessary for the synthesis of acetylcholine in the brain (20-22). A decrease in the number of cholinergic receptors and acetylcholine binding in the hippocampus was also observed in AD patients (23).

Another factor supporting the importance of acetylcholine in preserving memory is that $A D$ patients usually experience an improvement in memory at the start of treatment with acetylcholinesterase inhibitors such as donepezil, rivastigmine, and galantamine, although not permanent (24). When muscarinic receptors are blocked with scopolamine, memory encoding is also impaired (25).

\section{Factors influencing the action of bladder antimuscarinics in the CNS and specific pharmacological characteristics of solifenacin}

Choosing the safest anticholinergic for the CNS involves the following variables: lowest ability to cross the blood-brain barrier (BBB), being a substrate for P-glycoprotein, and lowest affinity for muscarinic M1R, which are mostly related to cognitive impairment $(26,27)$. P-glycoprotein is responsible for an efflux transport in the CNS, pumping molecules out and influencing the accumulation of drugs in the CNS (17). The BBB becomes more permissive in conditions such as aging, stroke, diabetes, trauma, multiple sclerosis, $A D$, and Parkinson's disease $(26,28)$. The BBB permeability is directly proportional to patient age due to the shrinkage of epithelial cells and opening of tight junctions (27). Hydrophobic, lipophilic, neutrally charged, and smaller molecules $(<400 \mathrm{kDa})$ can penetrate into the CNS more easily (29). In elderly patients, there are also fewer muscarinic receptors in the central nervous system, which could increase the effects of bladder antimuscarinics in the brain (30). The pharmacokinetics of individual drugs can also change with age. For example, a study of multiple doses of solifenacin ( 5 or $10 \mathrm{mg}$ ) in elderly patients (65 to 80 years) showed that Cmax (maximum concentration) and AUC (area under the plasma concentration-time curve 0-24 h) levels were 16\% and $20 \%$ higher, respectively, compared with younger volunteers (18 to 55 years). The $\mathrm{t} 1 / 2$ at the 5 -mg dose increased from $59 \mathrm{~h}$ in younger men to $75 \mathrm{~h}$ in older men and from 53 to $68 \mathrm{~h}$ in women (31).

Solifenacin succinate is a butanedioic acid salt with a molecular weight of $480.5 \mathrm{kDa}$, slightly basic (pKa 8.5), highly lipophilic with an octanol:water distribution of $50: 1$ at $\mathrm{pH} 7.0$, being $93 \%$ positively charged at $\mathrm{pH} 7.4$ (31).

Solifenacin, such as darifenacin, is a tertiary amine larger than other antimuscarinic agents like oxybutinin, presenting a lower capacity to penetrate the BBB $(32,33)$. However, solifenacin does not have an efflux mechanism like darifenacin, transported by P-glycoprotein, and trospium chloride, transported by a multidrug-resistanceassociated protein (MRP), which favors its accumulation in the CNS (33).

Cognitive dysfunctions induced by antimuscarinic agents are mediated mainly by the M1R and M2R in the CNS (34). If M1R and M2R are blocked, there may be changes in cognitive function, such as learning and memory deficits (27). In this sense, once the BBB is crossed, solifenacin binds to all muscarinic receptors (Table S1) but exhibits a relatively higher affinity and specificity for the muscarinic M3R subtype (pK1 affinity 8.0) than for the M1R (pKi affinity 7.6) and M2R (pKi affinity 6.9) subtypes (35-37).

Thus, despite being more selective for M3R, solifenacin also binds to M1R and M2R (35-37) and does not have a cerebral efflux mechanism (33), which could favor its accumulation in the CNS and provide long-term deleterious effects, especially in the elderly, who have greater permeability of the BBB and fewer muscarinic receptors in the CNS $(27,28)$.

The metabolism and elimination of solifenacin occurs mainly through non-renal mechanisms, and this drug is 
primarily metabolized in the liver with the production of 4 metabolites: M2 (N-oxide of solifenacin), M3 (4R-hydroxysolifenacin), M4 (4R-hydroxy N-oxide of solifenacin), and M5 (N-glucuronide of solifenacin) (38). The M2, M4, and M5 metabolites are inactive, with no pharmacological activity (38). Although the M3 metabolite has an affinity for muscarinic receptors similar to solifenacin (greater affinity for M3R), it has very low plasma concentrations and low potency, and its clinical effect is not significant $(29,31,38)$.

Two studies reported different findings regarding the possibility of solifenacin penetrating the BBB. Callegari et al. (39) reported that, of the antimuscarinics used in the treatment of $\mathrm{OAB}$, oxybutynin, solifenacin, and tolterodine had the highest cerebral concentration. Suzuki et al. (40), on the other hand, reported that solifenacin was rarely observed in the brain of rats, which may indicate that it does not significantly penetrate the BBB. In this study, Wistar rats aged 8 weeks were used and solifenacin was administered intravenously $10 \mathrm{~min}$ before the acquisition trials. The fact that young rats were used rather than older or senescent animals in the period, which would be equivalent to the age group in humans that most commonly use solifenacin, may have influenced the passage of solifenacin through the BBB $(27,28,41)$. Furthermore, the use of a single administration of solifenacin $10 \mathrm{~min}$ before the trial may not have been sufficient to cause adverse effects on memory, as in population-based studies these effects are more evident with chronic use of medications such as bladder antimuscarinics $(1,2,5,15)$.

\section{Effects of solifenacin on the CNS}

The influence of solifenacin and other antimuscarinic agents on muscarinic receptors in the brain has been measured in vitro. Jakobsen et al. (42) used a radio receptor bioassay to compare serum concentrations of antimuscarinics used in the treatment of $O A B$ with brain anticholinergic activity. They used tolterodine, oxybutynin, solifenacin, darifenacin, and 5-hydroxy-methyl-tolterodine (5-HMT, the active metabolite of fesoterodine). Tolterodine and 5-HMT had the highest anticholinergic activity, followed by oxybutynin. Solifenacin had one of the lowest anticholinergic activity, surpassing only darifenacin. A study by Suzuki et al. (40), in which the effect of various antimuscarinic drugs on learning was tested by performing a passive avoidance test in rats, presented evidence that oxybutynin and propiverine affected learning in a dosedependent manner. Darifenacin and solifenacin did not affect learning, according to their tests.

A study by Kobayashi et al. (43) shows that the inhibitory effects of solifenacin on $\mathrm{Ca} 2+$ mobilization stimulated by carbacol are equivalent to those of oxybutynin in detrusor cells, but much weaker in submandibular gland cells, suggesting that solifenacin has pharmacological selectivity in the bladder over other tissues. Maruyama et al. (44) evaluated the RO50 values (intravenous dose for $50 \%$ muscarinic receptor occupancy in the brain) and the inhibitory potency of increases in intravesical pressure (ID50) in an in vivo study in rats with intravenous injections of oxybutynin, propiverine, tolterodine, and solifenacin, through quantitative autoradiographic study. Considering the dose ratio (RO50/ID50) as a reflection of the selectivity of the bladder antimuscarinic agent in the brain, it was observed that this ratio was higher for solifenacin (8.146.7), tolterodine (3.6-17.9), and propiverine (2.2-8.9) than for oxybutynin (1.4-3.4), showing that solifenacin has greater selectivity for the bladder. Table 1 summarizes these in vitro and animal studies.

Despite the concern about the use of antimuscarinics in the elderly, there are clinical studies demonstrating the safety of solifenacin in relation to cognition. A randomized,

Table 1. Animal and in vitro studies with solifenacin.

\begin{tabular}{|c|c|c|c|c|}
\hline Reference & Type & Drugs & Duration of treatment & Results \\
\hline $\begin{array}{l}\text { Callegari } \\
\text { et al., } 2011 \text { (39) }\end{array}$ & $\begin{array}{l}\text { Male Sprague- } \\
\text { Dawley rats }\end{array}$ & $\begin{array}{l}\text { 5-HMT, darifenacin, } \\
\text { oxybutynin, solifenacin, } \\
\text { tolterodine, trospium }\end{array}$ & $\begin{array}{l}\text { Single dose of the compound } \\
\text { sc } 1 \mathrm{~h} \text { before animals } \\
\text { were euthanized }\end{array}$ & $\begin{array}{l}\text { Brain penetration was significant } \\
\text { for oxybutynin, solifenacin, } \\
\text { and tolterodine }\end{array}$ \\
\hline $\begin{array}{l}\text { Jakobsen } \\
\text { et al., } 2011 \text { (42) }\end{array}$ & $\begin{array}{l}\text { In vitro (anticholinergic } \\
\text { radio receptor bioassay) }\end{array}$ & $\begin{array}{l}\text { 5-HMT, darifenacin, } \\
\text { oxybutynin, solifenacin, } \\
\text { tolterodine }\end{array}$ & NA & $\begin{array}{c}\text { Solifenacin and darifenacin exhibited the } \\
\text { lowest anticholinergic activity compared to } \\
\text { the other drugs tested }\end{array}$ \\
\hline $\begin{array}{l}\text { Suzuki } \\
\text { et al., } 2007 \text { (40) }\end{array}$ & Male Wistar rats & $\begin{array}{l}\text { Darifenacin, oxybutynin, } \\
\text { propiverine, solifenacin, } \\
\text { tolterodine }\end{array}$ & $\begin{array}{l}\text { The drugs were } \\
\text { administered } \\
\text { iv } 10 \text { min before the } \\
\text { acquisition trials }\end{array}$ & $\begin{array}{l}\text { Solifenacin did not affect learning } \\
\text { in the passive avoidance test }\end{array}$ \\
\hline $\begin{array}{l}\text { Maruyama } \\
\text { et al., } 2008(44)\end{array}$ & $\begin{array}{l}\text { Male Sprague- } \\
\text { Dawley rats }\end{array}$ & $\begin{array}{l}\text { Darifenacin, oxybutynin, } \\
\text { propiverine, solifenacin, } \\
\text { tolterodine }\end{array}$ & $\begin{array}{l}\text { Single dose of compound iv } \\
40 \text { min before animals } \\
\text { were euthanized }\end{array}$ & $\begin{array}{c}\text { Solifenacin had a greater selectivity } \\
\text { for the bladder over the brain compared } \\
\text { to the other antimuscarinics }\end{array}$ \\
\hline
\end{tabular}

5-HMT: 5-hydroxymethyl tolterodine (the active metabolite of fesoterodine); sc: subcutaneously; iv: intravenously; NA: not assessed or not available. 
double-blind, triple-crossover study by Wagg et al. (30) with 26 patients older than 75 years and with mild cognitive impairment, comparing solifenacin $5 \mathrm{mg}$ once daily, oxybutynin $5 \mathrm{mg}$ twice daily, or placebo, during three treatment periods of 21 days each, separated by 21-day washout periods, concluded that solifenacin had no detectable effect on cognition, whereas oxybutynin was associated with a statistically significant decrease in both power and continuity of attention. The main side effects were mild, such as dry mouth and dyspepsia. In another randomized study, Kosilov et al. (32) evaluated 262 male patients, aged between 52 and 79 years, diagnosed with benign prostatic hyperplasia and $\mathrm{OAB}$, with a minimum score of 24 points on the Mini-mental State Examination (MMSE) scale. The patients were divided into three groups in which the same dosage of tamsulosin $(0.4 \mathrm{mg})$, different dosages of solifenacin (10 and $20 \mathrm{mg}$ ), and placebo were applied. After 8 weeks of study, there was no statistically significant variation in cognitive changes. Similar results were found in another study by Kosilov et al. (45) with 312 women, aged 60-83 years, with urge urinary incontinence or mixed urinary incontinence, with at least 24 points on the MMSE scale, who were randomized to solifenacin $20 \mathrm{mg}$ daily and trospium $60 \mathrm{mg}$ daily, solifenacin $10 \mathrm{mg}$ daily and trospium $30 \mathrm{mg}$ daily, or placebo. After an 8-week treatment period, there was no increased risk of cognitive impairment. The study by Wesnes et al. (46) analyzed the risk of cognitive impairment in the elderly comparing the use of $10 \mathrm{mg}$ of solifenacin, $10 \mathrm{mg}$ of oxybutynin, and placebo, without evidence of cognitive impairment with the use of $10 \mathrm{mg}$ of solifenacin compared to the placebo group. Oxybutynin, on the other hand, has been associated with impaired cognitive functions, particularly in impaired attention and sustained attention power, working memory, and alert self-assessment. Fifteen adverse effects occurred in 10 subjects taking oxybutynin and only 3 adverse effects occurred in 3 subjects taking solifenacin, with drowsiness as the only adverse effect. The VEGA study was another investigation of the cognitive effects of solifenacin in the elderly population. This was an observational study with 774 patients over 70 years of age and $O A B$, who were treated with solifenacin 5 or $10 \mathrm{mg}$ daily. After 12 weeks of treatment, no difference was observed in cognitive function evaluated with the MMSE scale (47). The use of solifenacin in stroke patients was also evaluated. Park conducted a follow-up study of stroke patients presenting symptoms of urgency and urinary frequency. Sixty-six patients received solifenacin (5 or $10 \mathrm{mg}$ ) and an age- and sex-matched control group of 66 subjects received placebo for 2 months. No significant difference was reported between groups in cognitive function (48).

The results of these studies show that the use of solifenacin in a short-term treatment (2 to 4 months) is safe, even in the elderly population using high daily doses of solifenacin, such as 20 to $30 \mathrm{mg}$ per day (see Table 2 for an overview).
Despite the demonstrated safety in short treatments, there are no long-term follow-up studies that specifically assess the chronic use of solifenacin and its effects on cognition. Studies investigating the long-term effects of anticholinergics on the CNS are restricted to grouping and evaluating drugs into categories such as bladder antimuscarinics, which does not take into account the molecular differences between each drug that may impact pharmacokinetics and action on the CNS. Coupland et al. (1) conducted a cohort nested case-control study from 2004 to 2016 with 58,769 case patients (diagnosed with dementia during follow-up) and 225,574 matched controls. They found that exposure to several types of strong anticholinergic drugs is associated with an increased risk of dementia. There was a significant increase in risk of dementia associated with bladder antimuscarinics, which was proportional to the total standardized daily doses (TSDDs), which reflects the level of patient exposure to the drug, with an adjusted odds ratio of 1.65 in the highest exposure category (>1095 TSDDs). The adjusted odds ratio (aOR) for TSDDs less than 90 was 1.19 , for TSDDs 91-365 the aOR was 1.35, and for TSDDs 366-1095 the aOR was 1.65 . This means that a shorter exposure to these antimuscarinics may not cause the same effects as with long-term use. In another nested case-control study using the UK's Clinical Practice Research Datalink, Richardson et al. (49) evaluated the association between newly diagnosed dementia patients and previous use of anticholinergics 4 to 20 years before the diagnosis of dementia. A total of 40,770 cases and 283,933 control subjects, aged 65-99 years, were included in the study. They concluded that there was a significant association between incidence of dementia and prescription of antidepressants, antiparkinsonians, or urological drugs with an anticholinergic cognitive burden (ACB) score of 3 . ACB 3 urological drugs (oxybutynin and tolterodine were 2 of the 5 most commonly prescribed anticholinergics in this study) prescribed $15-20$ years before the diagnosis of dementia showed a significant association with the incidence of dementia with an odds ratio of 1.27. Although solifenacin is not mentioned in that study, it is important to remember that this drug is classified as ACB 3 due to its high anticholinergic activity (50).

Gray et al. (2) conducted a prospective cohort study in which they evaluated 3,434 patients 65 years of age and older without dementia at study entry. They were followed for at least 10 years. During this study, 797 participants $(23 \%)$ developed dementia, and there was a relationship between cumulative use of anticholinergics and incidence of dementia. This ratio was proportional to the total standardized daily doses (TSDDs) of anticholinergics dispensed in the last 10 years, with an adjusted hazard ratio (aHR) of 1.54 (95\% confidence interval $(\mathrm{Cl})$ : 1.211.96) for risk of dementia incidence with cumulative anticholinergic use $>1095$ TSDDs (more than 3 years of use) and only an aHR of 0.92 of $(95 \% \mathrm{Cl}$ : $0.74-1.16)$ with 
Table 2. Short-term human studies with bladder antimuscarinics (solifenacin included).

\begin{tabular}{|c|c|c|c|c|c|c|}
\hline Reference & Design & Subjects (n) & Patients features & Antimuscarinics & $\begin{array}{l}\text { Duration of } \\
\text { treatment }\end{array}$ & Results summary \\
\hline $\begin{array}{l}\text { Wesnes et al., } \\
2009(46)\end{array}$ & $\begin{array}{c}\text { Randomized, } \\
\text { double-blind, } \\
\text { placebo-controlled } \\
\text { study }\end{array}$ & 12 patients & Over 65 years of age & $\begin{array}{c}10 \mathrm{mg} \mathrm{SOL}, 10 \mathrm{mg} \\
\text { OXY and PLA }\end{array}$ & $\begin{array}{c}3 \text { crossover } \\
\text { periods of single } \\
\text { dose treatment } \\
\text { separated by two } \\
\text { 14-day washout } \\
\text { periods }\end{array}$ & $\begin{array}{l}\text { No evidence of cognitive } \\
\text { impairment with the use of } \\
10 \text { mg solifenacin compared } \\
\text { to the placebo group. } \\
\text { Oxybutynin was associated } \\
\text { with impaired cognitive } \\
\text { functions (impaired attention } \\
\text { and continued attention } \\
\text { power, working memory and } \\
\text { alert self-assessment) }\end{array}$ \\
\hline $\begin{array}{l}\text { Wagg et al., } \\
2013(30)\end{array}$ & $\begin{array}{l}\text { Randomized, } \\
\text { double-blind, } \\
\text { triple-crossover } \\
\text { trial }\end{array}$ & 26 patients & $\begin{array}{l}\text { Patients over } 75 \text { years } \\
\text { of age and with mild } \\
\text { cognitive impairment }\end{array}$ & $\begin{array}{c}\text { SOL } 5 \text { mg once } \\
\text { daily, OXY } 5 \text { mg } \\
\text { twice daily, or PLA }\end{array}$ & $\begin{array}{l}3 \text { treatment periods } \\
\text { of } 21 \text { days each, } \\
\text { separated by } \\
21 \text {-day washout } \\
\text { periods }\end{array}$ & $\begin{array}{l}\text { Solifenacin had no } \\
\text { detectable effect on } \\
\text { cognition while oxybutynin } \\
\text { was associated with a } \\
\text { statistically significant } \\
\text { decrease in both power and } \\
\text { continuity of attention }\end{array}$ \\
\hline $\begin{array}{l}\text { Kosilov et al., } \\
2018(32)\end{array}$ & $\begin{array}{l}\text { Randomized study } \\
3 \text { groups }\end{array}$ & 262 patients & $\begin{array}{l}\text { Male patients aged } 52- \\
79 \text { years, diagnosed } \\
\text { with BPH and OAB, } \\
\text { with at least } 24 \text { points } \\
\text { on the MMSEs }\end{array}$ & $\begin{array}{l}\text { Same dosage of } \\
\text { TAM }(0.4 \mathrm{mg}) \text { and } \\
\text { different dosages of } \\
\text { SOL (10 and } \\
20 \mathrm{mg}) \text { and PLA } \\
\text { were applied: SOL } \\
10 \mathrm{mg}+\mathrm{TAM} \text { or } \\
\text { SOL } 20 \mathrm{mg}+\text { TAM } \\
\text { or PLA + TAM }\end{array}$ & 8 weeks & $\begin{array}{l}\text { No statistically significant } \\
\text { variation in relation to } \\
\text { cognitive changes }\end{array}$ \\
\hline $\begin{array}{l}\text { Kosilov et al., } \\
2018 \text { (45) }\end{array}$ & $\begin{array}{l}\text { Randomized study } \\
3 \text { groups }\end{array}$ & 312 patients & $\begin{array}{l}\text { Women, aged } 60-83 \\
\text { years, with urge urinary } \\
\text { incontinence or mixed } \\
\text { urinary incontinence, } \\
\text { with at least } 24 \text { points } \\
\text { on MMSEs }\end{array}$ & $\begin{array}{l}\text { SOL } 20 \mathrm{mg} / \mathrm{d} \text { and } \\
\text { TRO } 60 \mathrm{mg} / \mathrm{d} \text {, SOL } \\
10 \mathrm{mg} / \mathrm{d} \text { and TRO } \\
30 \mathrm{mg} / \mathrm{d} \text { or placebo: } \\
\text { SOL } 20 \mathrm{mg} / \mathrm{d} \text { or } \\
\text { TRO } 30 \mathrm{mg} / \mathrm{d} \text { or } \\
\text { PLA SOL } 10 \mathrm{mg} / \mathrm{d} \text { or } \\
\text { TRO } 30 \mathrm{mg} / \mathrm{d} \text { or } \\
\text { PLA }\end{array}$ & 8 weeks & $\begin{array}{c}\text { No increase in cognitive } \\
\text { impairment risk }\end{array}$ \\
\hline Park, 2013 (48) & $\begin{array}{l}\text { Retrospective } \\
\text { case-control study }\end{array}$ & $\begin{array}{l}66 \text { patients } \\
\text { with stroke } \\
66 \text { controls }\end{array}$ & $\begin{array}{c}\text { Stroke patients } \\
\text { presenting urinary } \\
\text { urgency and frequency } \\
\text { symptoms }\end{array}$ & $\begin{array}{c}\text { SOL } 5 \text { or } 10 \mathrm{mg} / \mathrm{d} \text { or } \\
\text { PLA }\end{array}$ & $\begin{array}{c}2 \text { months of } \\
\text { solifenacin use }\end{array}$ & $\begin{array}{l}\text { Solifenacin treatment did } \\
\text { not affect short-term } \\
\text { cognitive performance } \\
\text { (evaluated with MMSEs or } \\
\text { CDR-SB) in stroke patients }\end{array}$ \\
\hline $\begin{array}{l}\text { Triantafylidis } \\
\text { et al., } 2018(57)\end{array}$ & Systematic review & 4 studies & $\begin{array}{c}\text { Dual use of } \\
\text { cholinesterase } \\
\text { inhibitors and urinary } \\
\text { anticholinergics in older } \\
\text { adults }\end{array}$ & $\begin{array}{l}\text { Concomitant use of } \\
\text { cholinesterase } \\
\text { inhibitors and } \\
\text { urinary } \\
\text { anticholinergics }\end{array}$ & NA & $\begin{array}{l}\text { Inconclusive: no changes in } \\
\text { cognition in } 3 \text { studies } \\
\text { evaluated. Only one study } \\
\text { showing an improvement in } \\
\text { cognition with high doses of } \\
\text { donepezil and solifenacin }\end{array}$ \\
\hline $\begin{array}{l}\text { Hampel et al., } \\
2017 \text { (47) }\end{array}$ & $\begin{array}{l}\text { Observational } \\
\text { study }\end{array}$ & 774 patients & $\begin{array}{c}\text { Patients aged } \geqslant 70 \\
\text { years with } O A B\end{array}$ & $\mathrm{SOL} 5$ or $10 \mathrm{mg} / \mathrm{d}$ & 12 weeks & $\begin{array}{c}\text { No relevant effect of } \\
\text { solifenacin on cognitive } \\
\text { function in the MMSEs was } \\
\text { observed in this elderly } \\
\text { population }\end{array}$ \\
\hline
\end{tabular}

BPH: benign prostatic hyperplasia; CDR-SB: Clinical Dementia Rating Sum of Boxes; MMSEs: Mini-mental State Examination scale; NA: not assessed or not available; OAB: overactive bladder; OXY: oxybutynin; PLA: placebo; SOL: solifenacin; TAM: tamsulosin; TRO: trospium; d: day. 
1-90 TSDDs. The aHR for cumulative use of anticholinergics between 91-365 TSDDs was 1.19 (95\% Cl: 0.94-1.51) and the aHR for TSDDs 366-1095 was 1.23 (95\% $\mathrm{Cl}$ : $0.94-1.62)$. In this study, $19 \%$ of the patients used bladder antimuscarinics, which were associated with an increased risk of developing dementia. In a retrospective population-based case-control study evaluating 1 million people in Taiwan, the effects of bladder antimuscarinics on the development of dementia were examined. The study followed patients diagnosed with dementia $(20,246)$ and a control group without dementia $(40,394$ patients) aged 55 years and older with a mean age of 77 years, between 2000 and 2013, and excluded patients that used antimuscarinics for less than 1 year. The bladder antimuscarinics evaluated in this study were oxybutynin, solifenacin, tolterodine, propiverine, trospium, darifenacin, and fesoterodine. Patients using these medications exhibited a 2.46-fold increased risk of dementia compared to non-users $(95 \% \mathrm{Cl}$ : 2.22-2.73) (15). Given the predisposition of dementia events in diabetic patients who also have a higher incidence of $\mathrm{OAB}$, Yang et al. (6) studied the association of anticholinergics used in the treatment of $O A B$ with the incidence of dementia. In this cohort study, 10,938 patients using $\mathrm{OAB}$ anticholinergics (oxybutynin, solifenacin, or tolterodine) for more than 28 cumulative defined daily doses were compared with 594,733 patients not using these medications. At the end of the 6-year period, 7,774 patients had dementia. The rate of dementia events in this period was $3.9 \%$ in the oxybutynin group, $4.3 \%$ in the solifenacin group, $2.2 \%$ in the tolterodine group, and $1.2 \%$ in the control group $(P<0.001)$. The adjusted HRs of users compared to non-users of anticholinergic drugs was 2.35 (95\% Cl: 1.96 to 2.81$)$ for oxybutynin, $2.24(95 \% \mathrm{Cl}$ : 1.85 to 2.73$)$ for tolterodine, and $2.16(95 \% \mathrm{Cl}: 1.81$ to 2.58) for solifenacin, showing that the use of solifenacin in diabetic patients increases the relative risk for subsequent diagnosis of dementia, although this is lower compared to the other antimuscarinics evaluated.

These population-based studies showed an increased dementia risk in patients taking bladder antimuscarinics (including solifenacin) for a period longer than 1 year, or even for shorter periods in diabetic patients, and this should be taken into account when evaluating the benefitrisk of using these medications in the elderly population (see Supplementary Table S2). It is also important to consider the concomitant use of other anticholinergic drugs, keeping in mind the total cholinergic burden, that is, the cumulative effect of taking one or more medicines with anticholinergic properties (50). These studies did not mention sex-related differences in the incidence of dementia.

Polypharmacy, especially the use of potentially inappropriate medications, has been common in the elderly (51). Older adults are more susceptible to adverse drug reactions due to age-related changes in pharmacokinetics and pharmacodynamics and comorbidity from chronic conditions, such as cardiovascular diseases and psychological disorders (52-54). In a study of adults aged 65 years and older, poor health status was found to be associated with use of potentially inappropriate medications (55). The use of these potentially inappropriate medications is sometimes neglected even in patients diagnosed with dementia. This was shown in a longitudinal study with adults aged 65 years and older newly diagnosed with dementia, in which the use of these medications increased by $11 \%$ compared with the year of dementia diagnosis (56).

The use of bladder antimuscarinics in patients already diagnosed with dementia has raised concern. In a systematic review on concomitant use of cholinesterase inhibitors and urinary anticholinergics, Triantafylidis et al. (57) analyzed the cognitive and functional results and the prevalence of association of these drugs. The prevalence of dual therapy ranged from 1.2 to $40.5 \%$ and mixed results were found for cognitive and functional assessment with dual therapy, with 3 studies reporting no changes in cognition and one study reporting improvement in cognition with high doses of donepezil and solifenacin. Thus, due to these mixed results, this systematic review was inconclusive.

\section{Avoiding bladder antimuscarinics}

Antimuscarinic agents, such as solifenacin, are the first-line pharmacological treatment for OAB. However, mirabegron, a beta-3 agonist, has recently emerged as an alternative treatment that can prevent adverse CNS side effects of bladder antimuscarinics, which may be even more significant in patients already taking other antimuscarinics, thus avoiding an increase in total cholinergic burden. Total cholinergic burden should always be evaluated in polymedicated elderly patients, as it is a strong predictor of cognitive and physical impairments in these patients $(18,50,58,59)$.

Mirabegron was approved for clinical use in 2015 and has demonstrated efficacy and tolerability in the treatment of OAB. In 2016, Warren and colleagues published a review on mirabegron. It was concluded that the drug is effective in controlling $O A B$ symptoms and parameters such as number of micturitions per $24 \mathrm{~h}$, frequency of incontinence episodes, and mean volume voided per micturition after a 4-week treatment (60). Welk and McArthur (5) conducted a retrospective cohort study with data from 2010 to 2018 comparing the incidence of dementia in $47,324 \mathrm{OAB}$ patients treated with antimuscarinic agents and 23,662 treated with mirabegron. The group treated with antimuscarinics had a higher incidence of dementia compared to mirabegron $(\mathrm{HR}=1.23,95 \% \mathrm{Cl}: 1.12-1.35)$. Men and those younger than 75 years had a higher incidence of dementia induced by antimuscarinics compared to those taking mirabegron. There was no significant difference between classes of anticholinergics used (oxybutynin, 
tolterodine, solifenacin, darifenacin, fesoterodine, trospium), and the group treated with solifenacin had the same propensity to develop dementia as other groups treated with other anticholinergics.

\section{Discussion}

If antimuscarinics are chosen as a treatment option, it is recommended that all patients taking antimuscarinics who are at risk for cognitive impairment undergo periodic assessment of cognitive abilities using the MMSE scale (61). Memory changes in elderly patients are generally not noticed or reported by the patients themselves, making cognitive reassessment of elderly patients using antimuscarinics essential $(27,61,62)$. Another important consideration is the use of bladder antimuscarinics in some elderly or bedridden patients with cognitive impairment. In these patients, this treatment may not provide quality of life benefits because some of these patients are unaware of urinary loss and do not perceive the social impact of urinary incontinence, thus generally not compensating for the risk of using these drugs (63).

According to the articles described in this review, clinical studies that used solifenacin for a short period of up to 4 months showed no changes in cognition or increased incidence of dementia, showing that the use of this drug for a few months (up to 4 months) is safe, even in the elderly population using high daily doses of solifenacin, such as 20 to $30 \mathrm{mg}$ per day.

\section{References}

1. Coupland CAC, Hill T, Dening T, Morriss R, Moore M, Hippisley-Cox J. Anticholinergic drug exposure and the risk of dementia: a nested case-control study. JAMA Intern Med 2019; 179: 1084-1093, doi: 10.1001/jamainternmed.2019. 0677.

2. Gray SL, Anderson ML, Dublin S, Hanlon JT, Hubbard R, Walker $\mathrm{R}$, et al. Cumulative use of strong anticholinergic and incident dementia: a prospective cohort study. JAMA Intern Med 2015; 175: 401-407, doi: 10.1001/jamainternmed. 2014.7663.

3. Kachru N, Holmes HM, Johnson ML, Chen H, Aparasu RR. Risk of mortality associated with non-selective antimuscarinic medications in older adults with dementia: a retrospective study. J Gen Intern Med 2020; 35: 2084-2093, doi: 10.1007/s11606-020-05634-3.

4. Grossi CM, Richardson K, Fox C, Maidment I, Steel N, Loke $\mathrm{YK}$, et al. Anticholinergic and benzodiazepine medication use and risk of incident dementia: a UK cohort study. BMC Geriatr 2019; 19: 276, doi: 10.1186/s12877-019-1280-2.

5. Welk B, McArthur E. Increased risk of dementia among patients with overactive bladder treated with an anticholinergic medication compared to a beta-3 agonist: a populationbased cohort study. BJU Int 2020; 126: 183-190, doi: 10.1111/bju.15040.
However, population-based studies evaluating the use of bladder antimuscarinics or anticholinergics showed a statistically significant increase in the incidence of dementia when these medications were used for more than 1 year (>365 TSDDs). Shorter exposure to these antimuscarinics did not show the same risk of dementia as long-term use, except in diabetic patients who used more than 28 cumulative defined daily doses. The effects of using these drugs between 4 months and 1 year on cognition remain inconclusive.

Although several of these population-based studies included patients who used solifenacin, we are not aware of any specific long-term studies of solifenacin with regard to its effects on cognition or risk of dementia, which limits the conclusion of this review regarding the risk associated with prolonged use of this drug. Thus, until the safety of solifenacin is established by long-term studies, it seems advisable to avoid prolonged use of this drug in elderly patients.

\section{Supplementary Material}

Click here to view [pdf].

\section{Acknowledgments}

This study was supported by CNPq (\#309825/2017-2), CAPES (Project PROAP 88881.647234/2021-01), and the Ceará Foundation for the support of scientific and technological development (FUNCAP).

6. Yang YW, Liu HH, Lin TH, Chuang HY, Hsieh T. Association between different anticholinergic drugs and subsequent dementia risk in patients with diabetes mellitus. PLoS One 2017; 12(4): e0175335, doi: 10.1371/ journal.pone. 0175335 .

7. Roe CM, Anderson MJ, Spivack B. Use of anticholinergic medications by older adults with dementia. J Am Geriatr Soc 2002; 50: 836-842, doi: 10.1046/j.1532-5415.2002.50208.x.

8. Orme S, Morris V, Gibson W, Wagg A. Managing urinary incontinence in patients with dementia: pharmacological treatment options and considerations. Drugs Aging 2015; 32: 559-567, doi: 10.1007/s40266-015-0281-x.

9. Kachru N, Carnahan RM, Johnson ML, Aparasu RR. Potentially inappropriate anticholinergic medication use in older adults with dementia. J Am Pharm Assoc (2003) 2015; 55: 603-612, doi: 10.1331/JAPhA.2015.14288.

10. Yamada S, Ito Y, Nishijima S, Kadekawa K, Sugaya K. Basic and clinical aspects of antimuscarinic agents used to treat overactive bladder. Pharmacol Ther 2018; 189: 130-48, doi: 10.1016/j.pharmthera.2018.04.010.

11. Milsom I, Schiotz HA, Svensson M, Kilany S, Hansson F. A Nordic registry-based study of drug treatment patterns in overactive bladder patients. Scand J Urol 2019; 53: 246254, doi: 10.1080/21681805.2019.1619832. 
12. Kinlaw $A C$, Jonsson Funk $M$, Conover $M M$, Pate $V$, Markland AD, Wu JM. Impact of new medications and \$4 generic programs on overactive bladder treatment among older adults in the United States, 2000-2015. Med Care 2018; 56: 162-170, doi: 10.1097/MLR.0000000000000858.

13. Yeowell G, Smith P, Nazir J, Hakimi Z, Siddiqui E, Fatoye F. Real-world persistence and adherence to oral antimuscarinics and mirabegron in patients with overactive bladder (OAB): a systematic literature review. BMJ Open 2018; 8: e021889, doi: 10.1136/bmjopen-2018-021889.

14. Margulis $\mathrm{AV}$, Linder $\mathrm{M}$, Arana $\mathrm{A}$, Pottegård $\mathrm{A}$, Berglind $\mathrm{IA}$, Bui $C L$, et al. Patterns of use of antimuscarinic drugs to treat overactive bladder in Denmark, Sweden, and the United Kingdom. PLoS One 2018; 13: e0204456, doi: 10.1371/ journal.pone.0204456.

15. Harnod T, Yang YC, Chiu LT, Wang JH, Lin SZ, Ding DC. Use of bladder antimuscarinics is associated with an increased risk of dementia: a retrospective population-based case-control study. Sci Rep 2021; 11: 4827, doi: 10.1038/ s41598-021-84229-2.

16. Chiu MJ, Chen TF, Yip PK, Hua MS, Tang LY. Behavioral and psychologic symptoms in different types of dementia. J Formos Med Assoc 2006; 105: 556-562, doi: 10.1016/ S0929-6646(09)60150-9.

17. Gale SA, Acar D, Daffner KR. Dementia. Am J Med 2018; 131: 1161-1169, doi: 10.1016/j.amjmed.2018.01.022.

18. Fick DM, Semla TP, Steinman M, Beizer J, Brandt N, Dombrowski R, et al. American geriatrics society 2019 updated AGS Beers criteria ${ }^{\circledR}$ for potentially inappropriate medication use in older adults. J Am Geriatr Soc 2019; 67: 674-694, doi: 10.1111/jgs.15767.

19. Haam J, Yakel JL. Cholinergic modulation of the hippocampal region and memory function. $J$ Neurochem 2017; 142: 111-121, doi: 10.1111/jnc.14052.

20. Grothe M, Heinsen H, Teipel SJ. Atrophy of the cholinergic basal forebrain over the adult age range and in early stages of Alzheimer's disease. Biol Psychiatry 2012; 71: 805-813, doi: 10.1016/j.biopsych.2011.06.019.

21. Teipel S, Heinsen H, Amaro E, Grinberg LT, Krause B, Grothe M. Cholinergic basal forebrain atrophy predicts amyloid burden in Alzheimer's disease. Neurobiol Aging 2014; 35: 482-491, doi: 10.1016/j.neurobiolaging.2013.09.029.

22. Whitehouse PJ, Price DL, Struble RG, Clark AW, Coyle JT, DeLong MR. Alzheimer's disease and senile dementia: Loss of neurons in the basal forebrain. Science 1982; 215: 1237-1239, doi: 10.1126/science.7058341.

23. Parent MJ, Bedard MA, Aliaga A, Minuzzi L, Mechawar N, Soucy JP, et al. Cholinergic depletion in Alzheimer's disease shown by ( $18 \mathrm{~F}$ )FEOBV autoradiography. Int $\mathrm{J} \mathrm{Mol} \mathrm{Imaging}$ 2013; 2013: 205045, doi: 10.1155/2013/205045.

24. Ehret MJ, Chamberlin KW. Current Practices in the treatment of Alzheimer disease: where is the evidence after the phase III trials? Clin Ther 2015; 37: 1604-1616, doi: 10.1016/j.clinthera.2015.05.510.

25. Newman LA, Gold PE. Attenuation in rats of impairments of memory by scopolamine, a muscarinic receptor antagonist, by mecamylamine, a nicotinic receptor antagonist. Psychopharmacology 2016; 233: 925-932, doi: 10.1007/s00213015-4174-9.

26. Vouri SM, Schootman M, Strope SA, Birge SJ, Olsen MA. Differential prescribing of antimuscarinic agents in older adults with cognitive impairment. Drugs Aging 2018; 35: 321-331, doi: 10.1007/s40266-018-0531-9.

27. Araklitis G, Thiagamoorthy G, Hunter J, Rantell A, Robinson D, Cardozo L. Anticholinergic prescription: are healthcare professionals the real burden? Int Urogynecol J 2017; 28: 1249-1256, doi: 10.1007/s00192-016-3258-3.

28. Wagg A. Treating overactive bladder in the elderly. Can Urol Assoc J 2013; 5: 149-151, doi: 10.5489/cuaj.716.

29. Abrams $P$, Andersson KE. Muscarinic receptor antagonists for overactive bladder. BJU Int 2007; 100: 987-1006, doi: 10.1111/j.1464-410X.2007.07205.x.

30. Wagg A, Dale M, Tretter R, Stow B, Compion G. Randomised, multicentre, placebo-controlled, double-blind crossover study investigating the effect of solifenacin and oxybutynin in elderly people with mild cognitive impairment: The SENIOR study. Eur Urol 2013; 64: 74-81, doi: 10.1016/ j.eururo.2013.01.002.

31. Krauwinkel WJJ, Smulders RA, Mulder H, Swart PJ, Taekema-Roelvink MEJ. Effect of age on the pharmacokinetics of solifenacin in men and women. Int J Clin Pharmacol Ther 2005; 43: 227-238, doi: 10.5414/CPP43227.

32. Kosilov K, Kuzina I, Kuznetsov V, Gainullina Y, Kosilova L, Prokofyeva A, et al. Cognitive functions and health-related quality of life in men with benign prostatic hyperplasia and symptoms of overactive bladder when treated with a combination of tamsulosin and solifenacin in a higher dosage. Aging Male 2018; 21: 121-129, doi: 10.1080/ 13685538.2017.1398723.

33. Kay GG, Ebinger U. Preserving cognitive function for patients with overactive bladder: evidence for a differential effect with darifenacin. Int J Clin Pract 2008; 62: 1792-1800, doi: 10.1111/j.1742-1241.2008.01849.x.

34. Kay G, Crook T, Rekeda L, Lima R, Ebinger U, Arguinzoniz $M$, et al. Differential effects of the antimuscarinic agents darifenacin and oxybutynin ER on memory in older subjects. Eur Urol 2006; 50: 317-326, doi: 10.1016/j.eururo.2006. 03.057.

35. Ikeda K, Kobayashi S, Suzuki M, Miyata K, Takeuchi M, Yamada $\mathrm{T}$, et al. M3 receptor antagonism by the novel antimuscarinic agent solifenacin in the urinary bladder and salivary gland. Naunyn Schmiedebergs Arch Pharmacol 2002; 366: 97-103, doi: 10.1007/s00210-002-0554-x.

36. Pagoria D, O'Connor RC, Guralnick ML. Antimuscarinic drugs: review of the cognitive impact when used to treat overactive bladder in elderly patients. Curr Urol Rep 2011; 12: 351-357, doi: 10.1007/s11934-011-0198-9.

37. Ohtake A, Saitoh C, Yuyama H, Ukai M, Okutsu H, Noguchi $Y$, et al. Pharmacological characterization of a new antimuscarinic agent, solifenacin succinate, in comparison with other antimuscarinic agents. Biol Pharm Bull 2007; 30: 54-58, doi: 10.1248/bpb.30.54.

38. Doroshyenko O, Fuhr U. Clinical pharmacokinetics and pharmacodynamics of solifenacin. Clinical Pharmacokinet 2009; 48: 281-302, doi: 10.2165/00003088-20094805000001.

39. Callegari E, Malhotra B, Bungay PJ, Webster R, Fenner $\mathrm{KS}$, Kempshall S, et al. A comprehensive non-clinical evaluation of the CNS penetration potential of antimuscarinic agents for the treatment of overactive bladder. $\mathrm{Br} J$ Clin Pharmacol 2011; 72: 235-246, doi: 10.1111/j.13652125.2011.03961.x 
40. Suzuki M, Noguchi $Y$, Okutsu $H$, Ohtake A, Sasamata M. Effect of antimuscarinic drugs used for overactive bladder on learning in a rat passive avoidance response test. Eur $J$ Pharmacol 2007; 557: 154-158, doi: 10.1016/j.ejphar. 2006.11.054.

41. Abrams P, Andersson KE, Buccafusco JJ, Chapple C, De Groat WC, Fryer AD, et al. Muscarinic receptors: their distribution and function in body systems, and the implications for treating overactive bladder. Br J Pharmacol 2006; 148: 565-578, doi: 10.1038/sj.bjp.0706780.

42. Jakobsen SM, Kersten $H$, Molden E. Evaluation of brain anticholinergic activities of urinary spasmolytic drugs using a high-throughput radio receptor bioassay. J Am Geriatr Soc 2011; 59: 501-505, doi: 10.1111/j.15325415.2010.03307.x.

43. Kobayashi S, Ikeda K, Miyata K. Comparison of in vitro selectivity profiles of solifenacin succinate (YM905) and current antimuscarinic drugs in bladder and salivary glands: a Ca2 + mobilization study in monkey cells. Life Sci 2004; 74: 843-853, doi: 10.1016/j.lfs.2003.07.019.

44. Maruyama S, Tsukada H, Nishiyama S, Kakiuchi T, Fukumoto D, Oku N, et al. In vivo quantitative autoradiographic analysis of brain muscarinic receptor occupancy by antimuscarinic agents for overactive bladder treatment. J Pharmacol Exp Ther 2008; 325: 774-781, doi: 10.1124/ jpet.108.136390.

45. Kosilov K, Kuzina I, Loparev S, Gainullina Y, Kosilova L, Prokofyeva A. Influence of the short-term intake of high doses of solifenacin and trospium on cognitive function and health-related quality of life in older women with urinary incontinence. Int Neurourol J 2018; 22: 41-50, doi: 10.5213/ inj.1834996.498.

46. Wesnes KA, Edgar C, Tretter RN, Bolodeoku J. Exploratory pilot study assessing the risk of cognitive impairment or sedation in the elderly following single doses of solifenacin 10 mg. Expert Opin Drug Saf 2009; 8: 615-626, doi: 10.1517/14740330903260790.

47. Hampel C, Betz D, Burger M, Nowak C, Vogel M. Solifenacin in the elderly: results of an observational study measuring efficacy, tolerability and cognitive effects. Urol Int 2017; 98: 350-357, doi: 10.1159/000455257.

48. Park JW. The effect of solifenacin on cognitive function following stroke. dementia and geriatric cognitive disorders extra. Dement Geriatr Cogn Dis Extra 2013; 3: 143-147, doi: $10.1159 / 000350029$.

49. Richardson K, Fox C, Maidment I, Steel N, Loke YK, Arthur $\mathrm{A}$, et al. Anticholinergic drugs and risk of dementia: casecontrol study. BMJ 2018; 361: k1315, doi: 10.1136/bmj. k1315.

50. Salahudeen MS, Duffull SB, Nishtala PS. Anticholinergic burden quantified by anticholinergic risk scales and adverse outcomes in older people: a systematic review. BMC Geriatr 2015; 15: 31, doi: 10.1186/s12877-015-0029-9.

51. Mortazavi SS, Shati M, Keshtkar A, Malakouti SK, Bazargan M, Assari S. Defining polypharmacy in the elderly: a systematic review protocol. BMJ Open 2016; 6: e010989, doi: 10.1136/bmjopen-2015-010989.

52. Johnell K, Klarin I. The relationship between number of drugs and potential drug-drug interactions in the elderly. Drug Saf 2007; 30: 911-918, doi: 10.2165/00002018200730100-00009.

53. Nechba RB, El M'Barki Kadiri M, Bennani-Ziatni M, Zeggwagh AA, Mesfioui A. Difficulty in managing polypharmacy in the elderly: case report and review of the literature. J Clin Gerontol Geriatr 2015; 6: 30-33, doi: 10.1016/ j.jcgg.2014.06.002.

54. Fulton MM, Allen ER. Polypharmacy in the elderly: a literature review. J Am Acad Nurse Pract 2005; 17: 123132, doi: 10.1111/j.1041-2972.2005.0020.x.

55. Miller GE, Sarpong EM, Davidoff AJ, Yang EY, Brandt NJ, Fick DM. Determinants of potentially inappropriate medication use among community-dwelling older adults. Health Serv Res 2017; 52: 1534-1549, doi: 10.1111/1475-6773.12562.

56. Gnjidic D, Agogo GO, Ramsey CM, Moga DC, Allore H. The impact of dementia diagnosis on patterns of potentially inappropriate medication use among older adults. J Gerontol A Biol Sci Med Sci 2018; 73: 1410-1417, doi: 10.1093/ gerona/gly078.

57. Triantafylidis LK, Clemons JS, Peron EP, Roefaro J, Zimmerman KM. Brain over bladder: a systematic review of dual cholinesterase inhibitor and urinary anticholinergic use. Drugs Aging 2018; 35: 27-41, doi: 10.1007/s40266017-0510-6.

58. Cai X, Campbell N, Khan B, Callahan C, Boustani M. Longterm anticholinergic use and the aging brain. Alzheimers Dement 2013; 9: 377-385, doi: 10.1016/j.jalz.2012.02.005.

59. Carrière I, Fourrier-Reglat A, Dartigues JF, Rouaud $O$, Pasquier F, Ritchie K, et al. Drugs with anticholinergic properties, cognitive decline, and dementia in an elderly general population: the 3-city study. Arch Int Med 2009; 169: 1317-1324, doi: 10.1001/archinternmed.2009.229.

60. Warren K, Burden H, Abrams P. Mirabegron in overactive bladder patients: efficacy review and update on drug safety. Ther Adv Drug Saf 2016; 7: 204-216, doi: 10.1177/2042 098616659412.

61. Gormley EA, Lightner DJ, Burgio KL, Chai TC, Clemens JQ, Culkin DJ, et al. Diagnosis and treatment of overactive bladder (non-neurogenic) in adults: AUA/SUFU guideline. J Urol 2012; 188: 2455-2463, doi: 10.1016/j.juro.2012.09. 079.

62. Paquette A, Gou P, Tannenbaum C. Systematic review and meta-analysis: do clinical trials testing antimuscarinic agents for overactive bladder adequately measure central nervous system adverse events? J Am Geriatr Soc 2011; 59: 13321339, doi: 10.1111/j.1532-5415.2011.03473.x.

63. Perk S, Wielage RC, Campbell NL, Klein TM, Perkins A, Posta LM, et al. Estimated budget impact of increased use of mirabegron, a novel treatment for overactive bladder. J Manag Care Spec Pharm 2016; 22: 1072-1084, doi: 10.18553/jmcp.2016.22.9.1072. 